\title{
Study on the Seismogenic Mechanism of the Earthquake Mw6.9 in 2014 in the Aegean Sea Seismic Cone
}

\author{
Lijun Chen \\ Earthquake Administration of Hunan Province, Changsha, China \\ Email: seisman@foxmail.com
}

Received 31 March 2016; accepted 20 May 2016; published 23 May 2016

Copyright (C) 2016 by author and Scientific Research Publishing Inc.

This work is licensed under the Creative Commons Attribution International License (CC BY). http://creativecommons.org/licenses/by/4.0/

c) (i) Open Access

\begin{abstract}
In accordance with the Seismo-Geothermics theory about methods of intracrustal strong earthquake and volcano prediction, we use the ANSS earthquake catalogue from the Northern California earthquake data center and the EMSC earthquake catalogue from the European-Mediterranean Seismological Centre to study the seismic activities of the Turkish Branch Seismic Cone in the Mediterranean Seismic Cone and the following Aegean Sea Seismic Cone, and show reproduction through graphics and animation, the seismogenic process and seismogenic mechanism of the earthquake Mw6.9 on May 24, 2014 in northern Aegean Sea. It was concluded that the energy of strong earthquake of magnitude around 7 in Aegean Sea was probably from energy transfer and accumulation in deep mantle and incentive lithosphere in the way of wave pattern, and then the strong earthquake occurs suddenly in search of the weak parts of the surface structure. The purpose of this paper is to open a hole in the traditional seismic genesis, and it is beneficial to the further research on the theory and method of earthquake prediction. It is our first attempt to study this case and it needs further examination. In this paper, we divide the Turkish Branch Seismic Cone of the Mediterranean Seismic Cone into 4 tertiary seismic cones, and we show a preliminary seismo-tectonic model of Aegean region. It will be conducive to seismic monitoring and earthquake prediction research in Greece, Turkey, Romania and Poland regions. At present, the world's earthquake prediction has little effect, and it even tends to be not cognitive. Innovative thinking is the only way out.
\end{abstract}

\section{Keywords}

Seismo-Geothermics Theory, Seismic Cone, Turkey, Aegean Sea, Subcrustal Earthquake, Intracrustal Strong Earthquake, Seismogenic Mechanism 


\section{Introduction}

Using the ANSS earthquake catalogue of magnitude 4+ from the Northern California earthquake data center and the EMSC earthquake catalogue of magnitude 1+ from the European-Mediterranean Seismological Centre, according to the author's about Seismo-Geothermics theory and method [1]-[3], the seismic activity space distribution and time course of earthquakes in the Turkish Branch Seismic Cone of the Mediterranean Seismic Cone are studied and the seismogenic process of the earthquake of magnitude Mw6.9 on May 24, 2014 in northern Aegean Sea is given in this paper.

So far, people often think that earthquake preparation and occurrence are due to the strain energy accumulation of near surface geological tectonic movement (fault or fold), and it requires assumptions of the subduction zone and interpretation by phase transformation, so are intracrustal strong earthquakes and deep seismic activities. However, the results of this study indicate that the energy accumulation of intracrustal strong earthquakes can be derived from the upper mantle, and intracrustal strong earthquakes may be related to the crustal structure just before its occurrence. This result opens a small gap to the traditional seismic genesis, and may also change the theory and method of earthquake prediction.

\section{Data Selection and Research Methods}

The data of the seismicity research of Turkey and the Aegean Sea in this paper is local and the research method is global. We have made some experimental examples [4]-[8].

\subsection{Research Methods}

The research method used in this paper is based on the theory and working methods of Seismo-Geothermics theory proposed by the author.

Seismo-Geothermics theory suggested that global strong earthquakes and volcanic activity are control by a hot engine belt tectonic system and a cooling seismic belt tectonic system in the Earth; the hot engine belt is composed of 24 known seismic cones defined by the author, which controls all global deep earthquakes, 92\% of the intracrustal strong earthquakes, and $83 \%$ of volcano activities. It is a dynamic zone of global geological disasters with M-type distribution on the Earth; the cooling seismic belt is mainly along the ocean ridge appearing shallow earthquakes and volcanic activity and is an adjustment of the global geological disaster zone with W-shaped distribution (Figure 1).

The concept of the Seismic Cone structure, which was called as seismic cylinder or seismic mantle plume, is constructed compositely by one or more monomer seismic cone, and the known maximum depth is $740 \mathrm{~km}$. Single seismic cone structure is an inverted cone integrated by deep seismic source density with independent active layers (with constant heat layer), energy storage layer and dissipative layer of affected areas. The earthquake is marked by the heat driving from the bottom and up layer by layer. The heat accumulation in the storage layer provides thermal mass and the heat energy of volcanic eruption, and/or it changes into needed mechanical energy for strong earthquake in the crust, pushed to the surface tectonic activities.

At present, the seismic prediction method of Seismo-Geothermics theory is only applicable to the hot engine belt. For the known 24 seismic cones, the methods of work are:

- To collect information of earthquake and volcano activities in related geographic range.

- To use temporal and spatial analysis to analyze the seismic data; to identify rationality of cone structure and division of internal monomer cone structure.

- To determine the future activity intensity, abnormal possible place, and abnormal periods on seismic analysis of spatial and temporal of subcrustal earthquakes.

- To comprehensively analyze the anomalies, and to determine the possibility of volcano eruption or possibility of intracrustal strong earthquakes.

- To analyze the Earthquake cause and summarize cases; to improve principle and working method of SeismoGeothermics theory.

\subsection{Data Selection}

The research scope of this paper is the Aegean Sea and the surrounding area, which is limited to the Turkish Branch Seismic Cone of the Mediterranean Seismic Cone No. 19, namely, $30^{\circ}-55^{\circ} \mathrm{N}, 17^{\circ}-39^{\circ} \mathrm{E}$. 


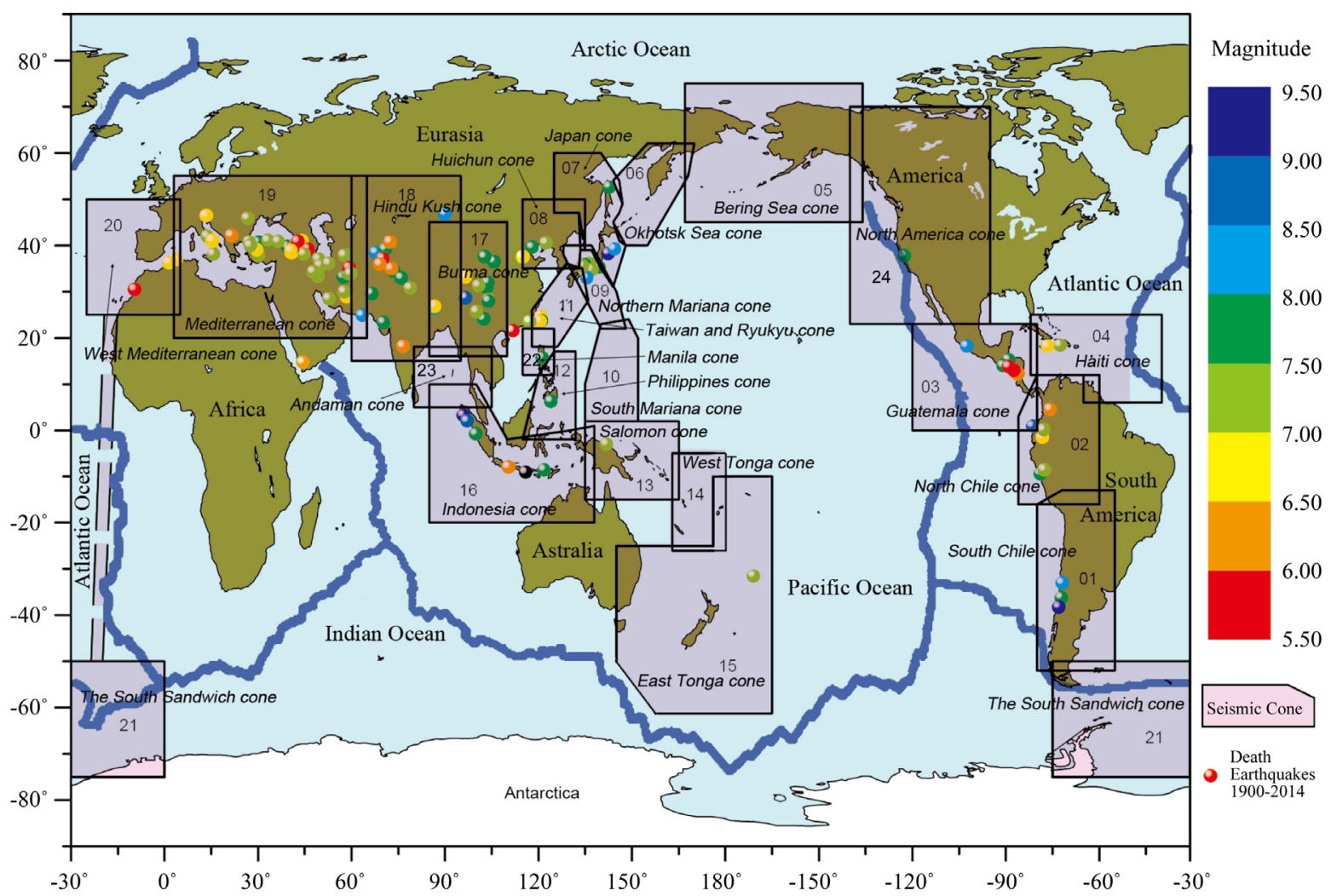

Figure 1. Schematic diagram of global structural system by Seismo-Geothermics theory.

The strong earthquake data is from earthquake catalogue of ANSS by the Northern California earthquake data center and we have got data of 11,653 earthquakes of magnitude 4 and above between 1963 to 2016 years. Among them, there are 10,726 earthquakes of M4 - 4.9, 851 earthquakes of M5 - 5.9, 72 earthquakes of M6 6.9 and 4 earthquakes of M7 - 7.9. The maximum magnitude is 7.7 and the maximum focal depth is $226 \mathrm{~km}$.

The microseismic data is from Mediterranean seismic data center (EMSC) and it provides 97,536 earthquakes of magnitude 1 and above in the period from Oct.1, 2004 to Oct.1, 2015. Among them, there are 4226 earthquakes of M1 - 1.9, 62,110 earthquakes of M2-2.9, 28,642 earthquakes of M3 - 3.9, 2393 earthquakes of M4 4.9, 150 earthquakes of M5 - 5.9, and 15 earthquakes of M6 - 6.9. The maximum earthquake is 6.9 and the maximum focal depth is $667 \mathrm{~km}$.

The number of earthquakes of M2.5 and below is too few apparently (Figure 2), but the space distribution still has statistical significance, and it fails to eliminate.

\section{Seismic Activity of the Turkish Branch Seismic Cone}

The Turkish Branch of the Mediterranean Seismic Cone, or the Turkish Branch Seismic Cone for short, is a second level branch cone of the Mediterranean Seismic Cone No.19 in global 24 seismic cones [2] [3].

Figure 1 shows the global earthquakes with 1000 or More Deaths in 1900-2014 [9] and the number of death earthquakes is the largest in the Mediterranean region. Figure 2 shows the reliability of the seismic network monitoring in the Mediterranean region since Oct.1, 2004. Therefore, this paper focuses on the study of the seismic activity of the Turkish Branch Seismic Cone, which may help to find the solution of earthquake prediction, and also help to enhance the security of human life in the area.

\subsection{The Mid-Strong Earthquake Activity of the Turkish Branch Seismic Cone}

According to the ANSS earthquake catalogue of the Northern California earthquake data center, the geographic distribution and the stereo image in the Turkish Branch Seismic Cone are shown in Figure 3 and Figure 4 respectively. 


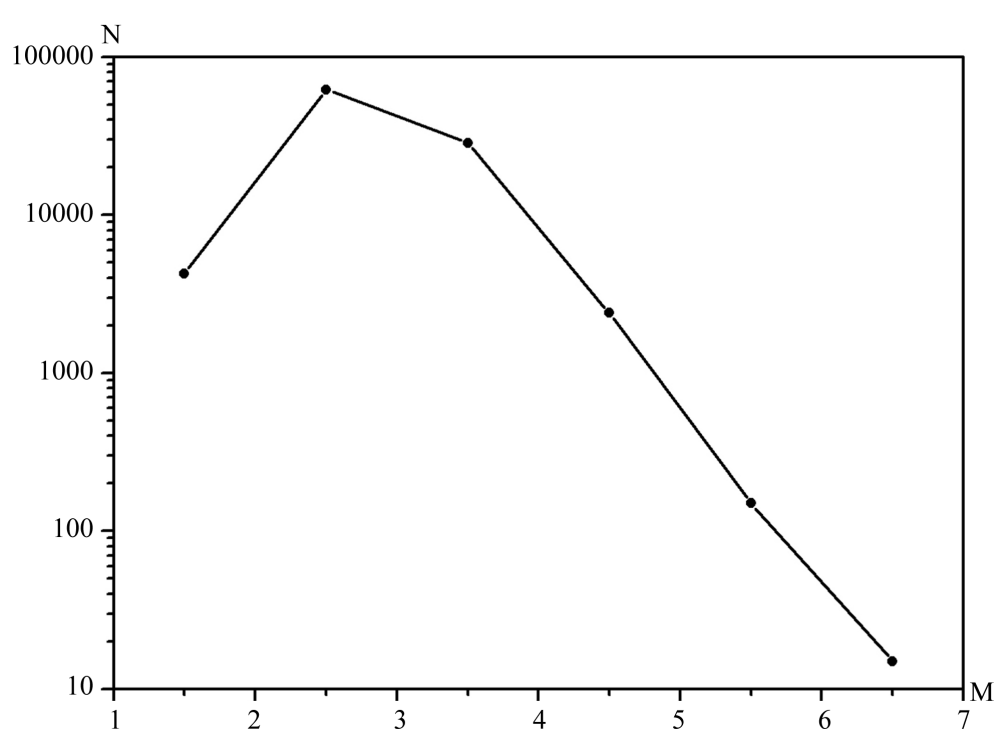

Figure 2. The repetition rate of the Turkish Branch Seismic Cone.

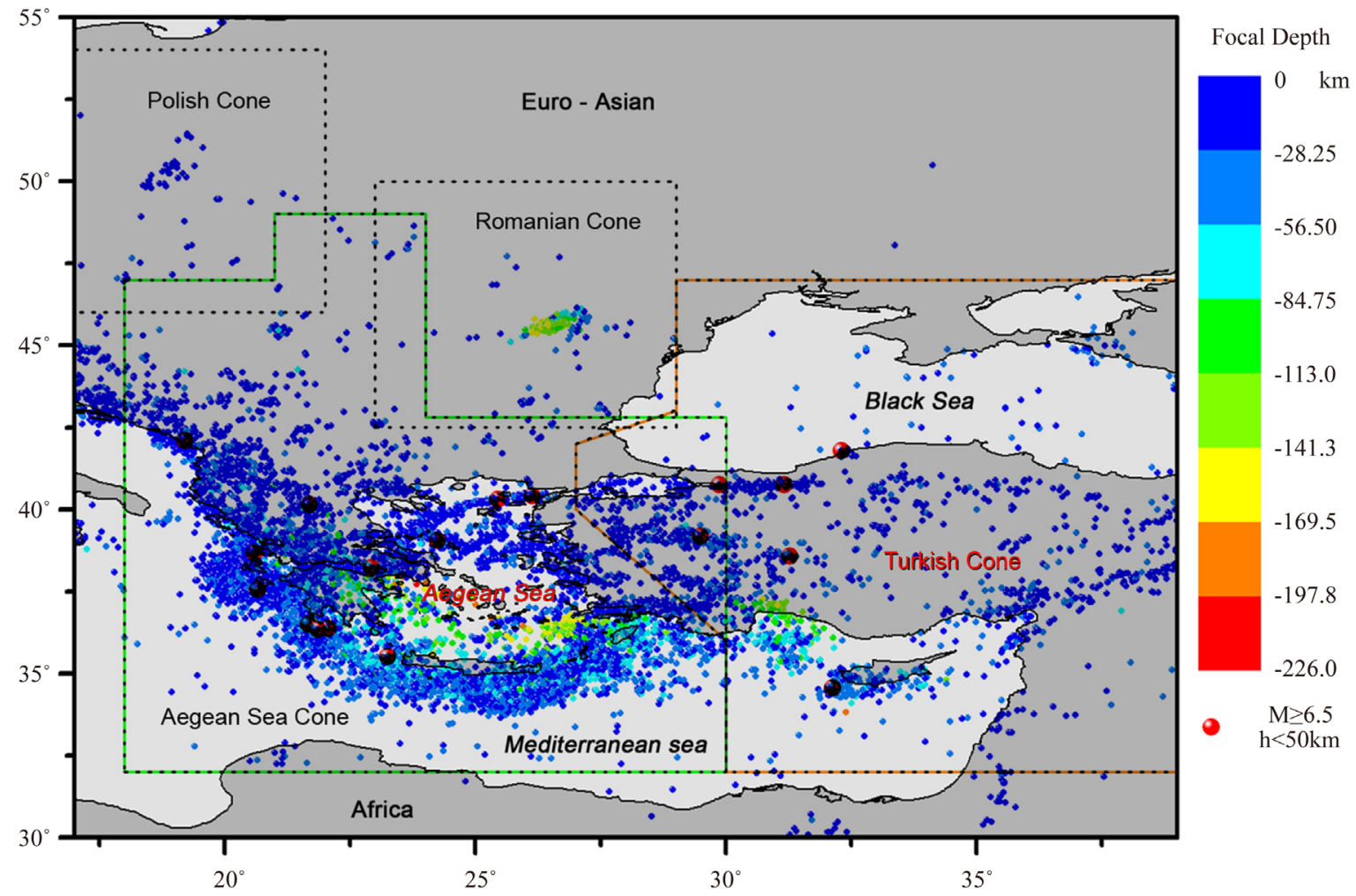

Figure 3. Geographical distribution map in the Turkish Branch Seismic Cone (Jan.1, 1963 - Mar.2, 2016, M $\geq 4$ ).

For Figure 3, the earthquakes are mainly distributed along the north shore of the Mediterranean Sea where the famous Mediterranean-Himalaya zonal belt lies on [10] [11]. Around Aegean Sea, the seismic activity, which is a ring-like distribution, and the Solomon's ring-like distribution constitute two largest earthquake landscape structures on the Earth.

Figure 4 shows the space distribution of Turkey Branch earthquakes. There are several inverted cones, which are formed by the focal dense collective of the Turkey Branch. This is consistent with the author's concept about 


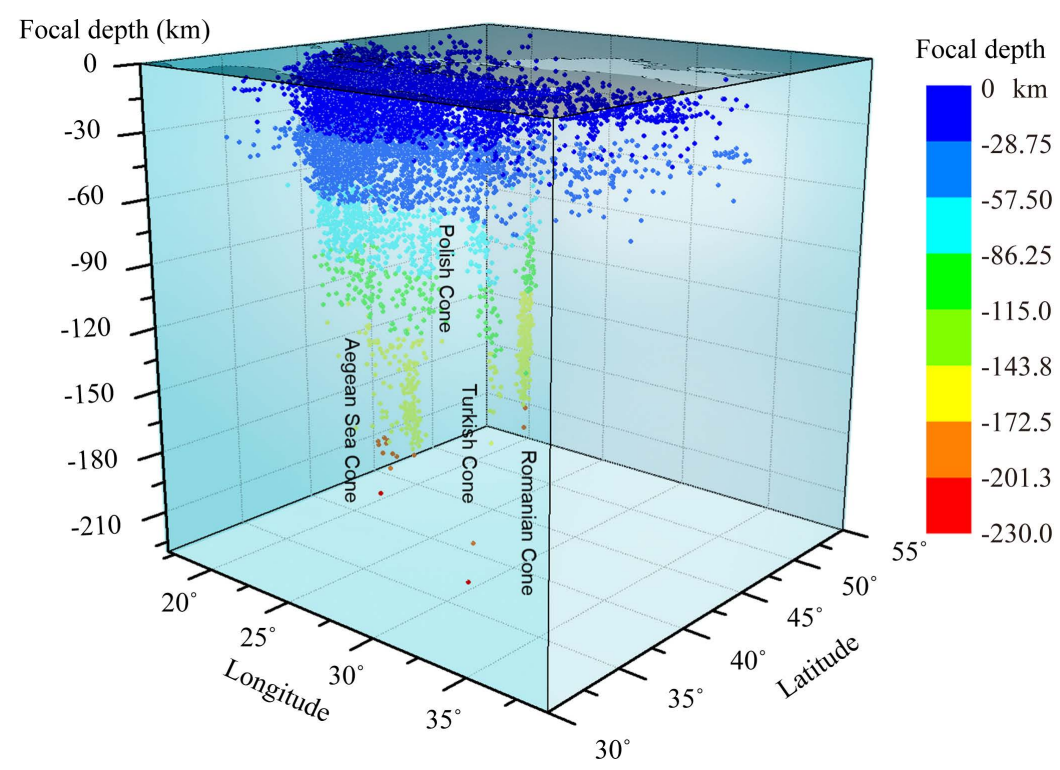

Figure 4. The three-dimensional distribution map in the Turkish Branch Seismic Cone (Jan.1, 1963 - Mar.2, 2016, M $\geq 4$ ).

the seismic cone and its pillar structure [3]. The cone forms are from seismic data of more than 50 years and the image is stable.

Figure 3 and Figure 4 show that the Turkish Branch Seismic Cone can be subdivided into a number of single seismic cones (after detailed).

\subsection{Analysis of Microseismic Data of the Turkish Branch Seismic Cone}

According to the ESMC earthquake catalogue from the European-Mediterranean Seismological Centre, the geographical distribution and the three-dimensional image of the Turkish Branch Seismic Cone are shown in Figure 5 and Figure 6 respectively.

Comparing Figure 4 with Figure 6, the images are basically similar, which shows that the compiled principles of two sets of earthquake catalogues are basically the same. The difference between the two sets of earthquake catalogues lies in the accuracy of seismic observation. The maximum focal depth is more than $600 \mathrm{~km}$ from ESMC earthquake catalogue but it did not change the position and shape of the cones.

\subsection{Seismic Cone Division of the Turkish Branch Seismic Cone}

See Figure 3, Figure 4 and Figure 6, the Turkish Branch Seismic Cone can be divided into 4 three-level seismic cones, such as Aegean Sea, Turkey, Romania, and Poland, which are divided by the data of subcrustal earthquake activities ( $\mathrm{h}>35 \mathrm{~km}$ ) of microseismic data in Figure 7 and the results of all of the figures are consistent. Each cone has the basic features of a single seismic cone, such as its pillar and its independence of affected area [3]. At present, the data of the Aegean Sea Seismic Cone and the Turkish Seismic Cone are rich enough, but the other two seismic cones are only beginning to take shape because of the insufficient information.

In Figure 7, the dashed line indicates the approximate boundary of the affected area (Table 1), the yellow arrow indicates the dip direction of the cone pillar (also called the intrinsic profile). The intrinsic profile of seismic cone is directed to the deep seismic active area, and is penetrated through the axial direction of cone. Along the section of the intrinsic profile, it can be painted in the only one section, which senses the individual Benioff section of monomer seismic cone. The intrinsic profile is one of the basic attributes of seismic cone structure. Its physical meaning and tectonic significance will be lost outside the seismic cone.

To the detailed studies of earthquakes, it is preferably microseismic data below magnitude 4 synchronously. However, the Mediterranean seismic data center provided a formal earthquake catalog just since October 2004, which showed about 7 strong earthquake occurred during the period only in the Aegean Sea. Because of this, the 


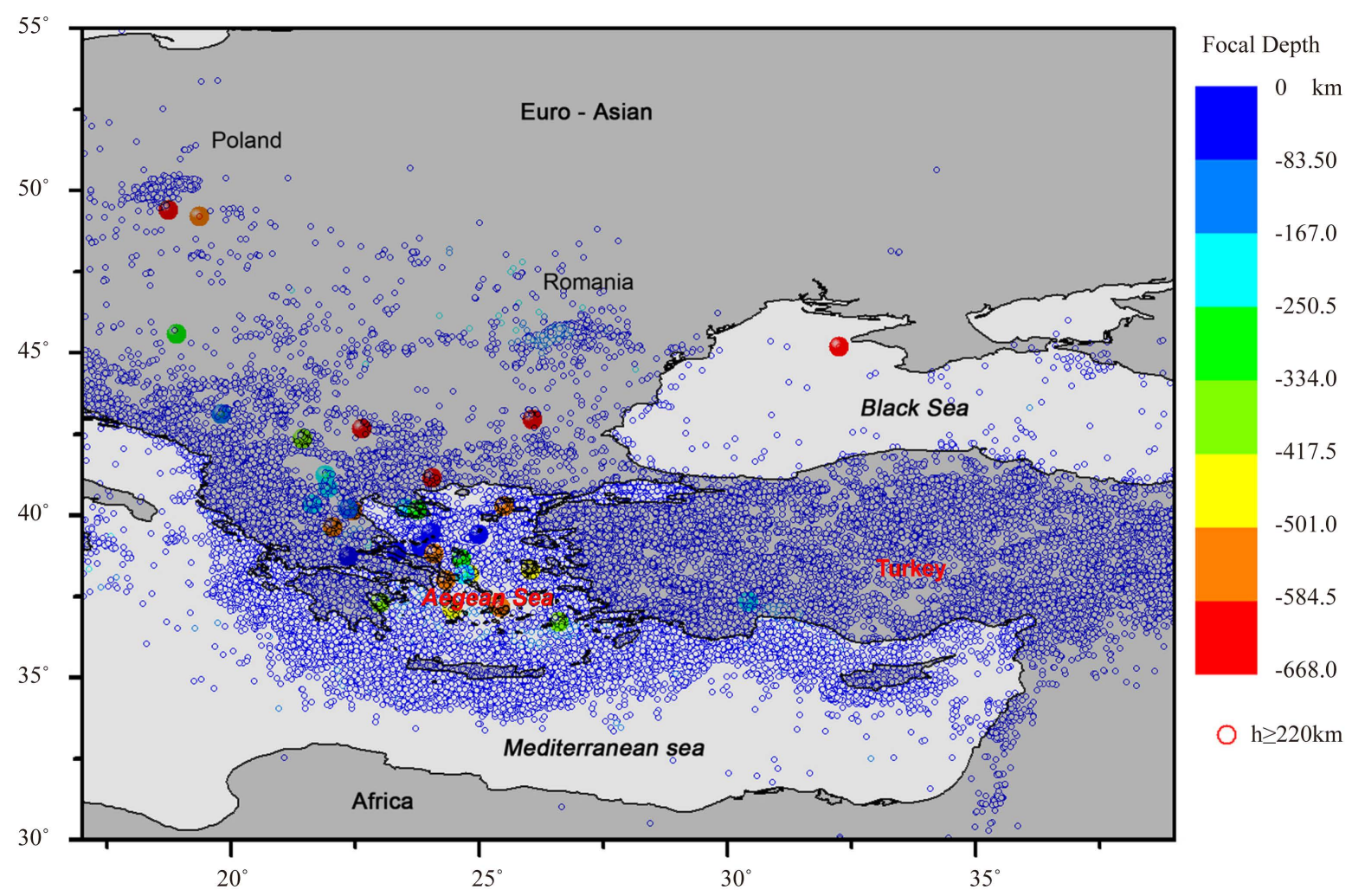

Figure 5. Geographical distribution map of microseismic activity in the Turkish Branch Seismic Cone (Oct.1, 2004 - Oct.1, 2015, $M \geq 1.7$ ).

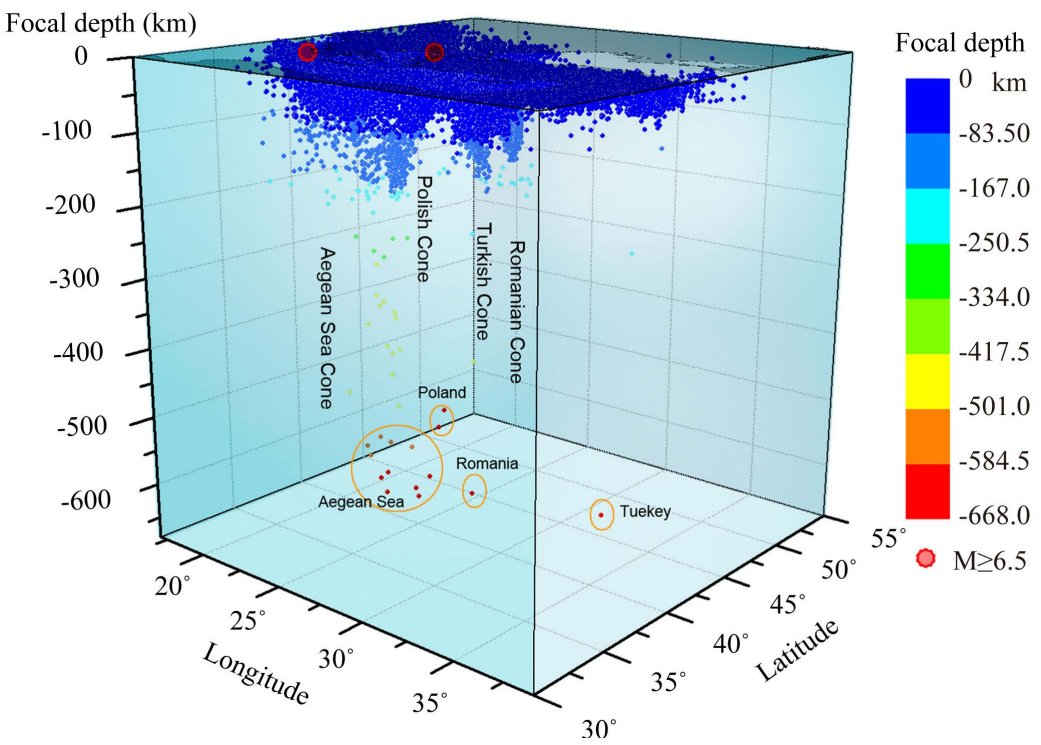

Figure 6. The three-dimensional distribution map of microseismic activity in the Turkish Branch Seismic Cone (Oct.1, 2004 - Oct.1, 2015, M $\geq 1.7$ ).

following research is focused on earthquake situation of the Aegean Sea Seismic Cone by ESMC catalog.

\section{Seismic Activity of the Aegean Sea Seismic Cone}

According to the seismic cone division in Figure 7, the geographical range of the Aegean Sea Seismic Cone is 
55

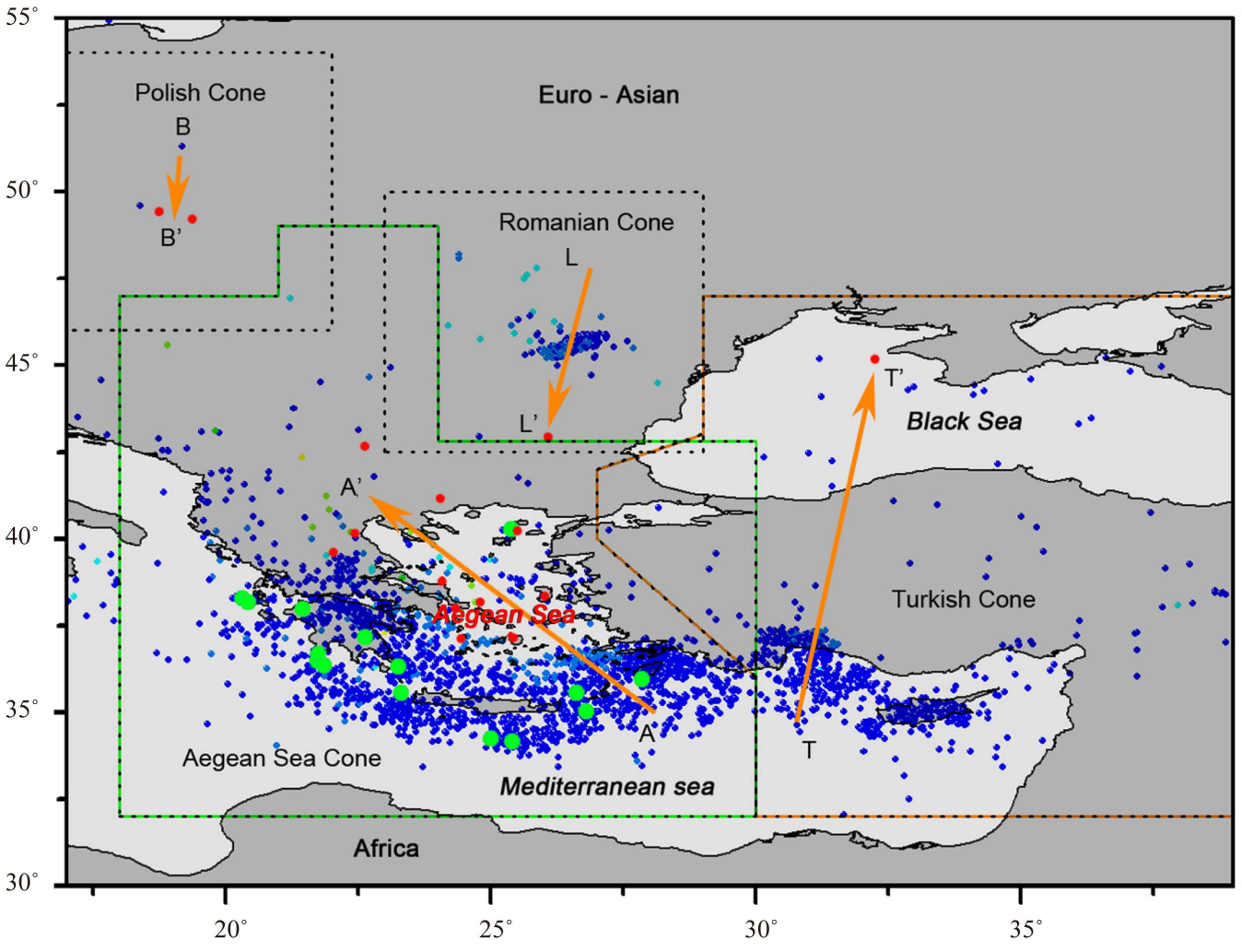

Focal Depth

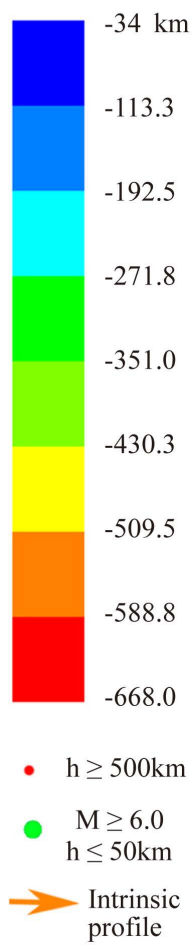

Figure 7. Earthquake distribution and cone division of the Turkish Branch Seismic Cone (Oct.1, 2004 - Oct.1, 2015, M $\geq$ 1.0).

Table 1. The seismic cone division of the Turkish Branch Seismic Cone (Oct.1, 2004 - Oct.1, 2015)*.

\begin{tabular}{cccccc}
\hline Seismic Cone & $\begin{array}{c}\text { Polygon Coordinate } \\
\text { Longitude, Latitude (degrees) }\end{array}$ & $\mathrm{N}$ & Hmax (km) & $\begin{array}{c}\text { Mmax } \\
\text { since } 2004\end{array}$ & $\begin{array}{c}\text { Mmax since } \\
1963\end{array}$ \\
\hline Aegean Sea & $\begin{array}{c}18,32-30,32-30,42.8-24,42.8-24, \\
49-21,49-21,47-18,47\end{array}$ & 75,573 & 667 & 6.9 & 6.9 \\
Turkish & $\begin{array}{c}30,32-30,36-27,40-27,42-29, \\
43-29,47-39,47-39,32\end{array}$ & 31,225 & 650 & 5.9 & 7.7 \\
Romanian & $23-29,42.5-50$ & 2046 & 650 & 6 & 7.1 \\
Polish & $17-22,46-54$ & 1063 & 650 & 4.7 & 5.1 \\
\hline
\end{tabular}

*N—number of earthquakes M1+, hmax-Maximum focal depth, Mmax—Maximum magnitude.

32 degrees to 44 degrees north and 18 degrees to 30 degrees east, including the Aegean Sea and its surrounding areas. Since 2004, there were 15 earthquakes with magnitude 6.0 or above occurred including 5 earthquakes of depth $35 \mathrm{~km}$ and above in the region, the maximum earthquake magnitude was 6.9 (Table 2 and Figure 8). Therefore the Aegean Sea Seismic Cone is one of the frequent earthquake regions in the Turkish Branch Seismic Cone. Because the microseismic activity in this area is frequent, the following research is mainly about the subcrustal earthquake activity.

\subsection{Subcrustal Seismic Activity of the Aegean Sea Seismic Cone Since 2004}

The geographical distribution of the earthquake with a depth of more than $35 \mathrm{~km}$ in the Aegean Sea is shown in Figure 8. The earthquakes in the graph are roughly concentrated in two belts. Among them, the rose thick dashed line I is the Greek arc and the yellow thick dashed line II is the Volcano arc, which has been commonly defined. According to the distribution pattern of the subcrustal earthquakes, this paper considers that the rose 
Table 2. The earthquake catalog of magnitude 6 or more in the Aegean Sea Seismic Cone (Oct.1, 2004 - Oct.1, 2015).

\begin{tabular}{|c|c|c|c|c|c|}
\hline $\begin{array}{c}\text { Date } \\
\text { (yyyy/mm/dd) }\end{array}$ & $\begin{array}{c}\text { Time } \\
\text { (hh:mm:ss) }\end{array}$ & $\begin{array}{l}\text { Latitude } \\
\text { (Degrees) }\end{array}$ & $\begin{array}{c}\text { Longitude } \\
\text { (Degrees) }\end{array}$ & $\begin{array}{l}\text { Magnitude } \\
\text { (Mw) }\end{array}$ & $\begin{array}{r}\text { Depth } \\
\text { (km) }\end{array}$ \\
\hline 20060108 & 113453 & 36.31 & 23.25 & 6.7 & 60 \\
\hline 20080106 & 051418 & 37.16 & 22.64 & 6.2 & 72 \\
\hline 20080214 & 100922 & 36.57 & 21.75 & 6.9 & 30 \\
\hline 20080214 & 120854 & 36.34 & 21.86 & 6.2 & 20 \\
\hline 20080220 & 182707 & 36.47 & 21.71 & 6.2 & 26 \\
\hline 20080608 & 122528 & 37.97 & 21.48 & 6.4 & 5 \\
\hline 20080715 & 032635 & 35.96 & 27.86 & 6.4 & 60 \\
\hline 20090701 & 093011 & 34.13 & 25.42 & 6.4 & 30 \\
\hline 20110401 & 132911 & 35.54 & 26.63 & 6.0 & 60 \\
\hline 20130615 & 161059 & 34.23 & 25.00 & 6.2 & 10 \\
\hline 20131012 & 131154 & 35.56 & 23.31 & 6.4 & 47 \\
\hline 20140126 & 135543 & 38.19 & 20.41 & 6.1 & 18 \\
\hline 20140203 & 030845 & 38.26 & 20.32 & 6.0 & 2 \\
\hline 20140524 & 092502 & 40.29 & 25.40 & 6.9 & 27 \\
\hline 20150416 & 180744 & 35.03 & 26.81 & 6.1 & 30 \\
\hline
\end{tabular}

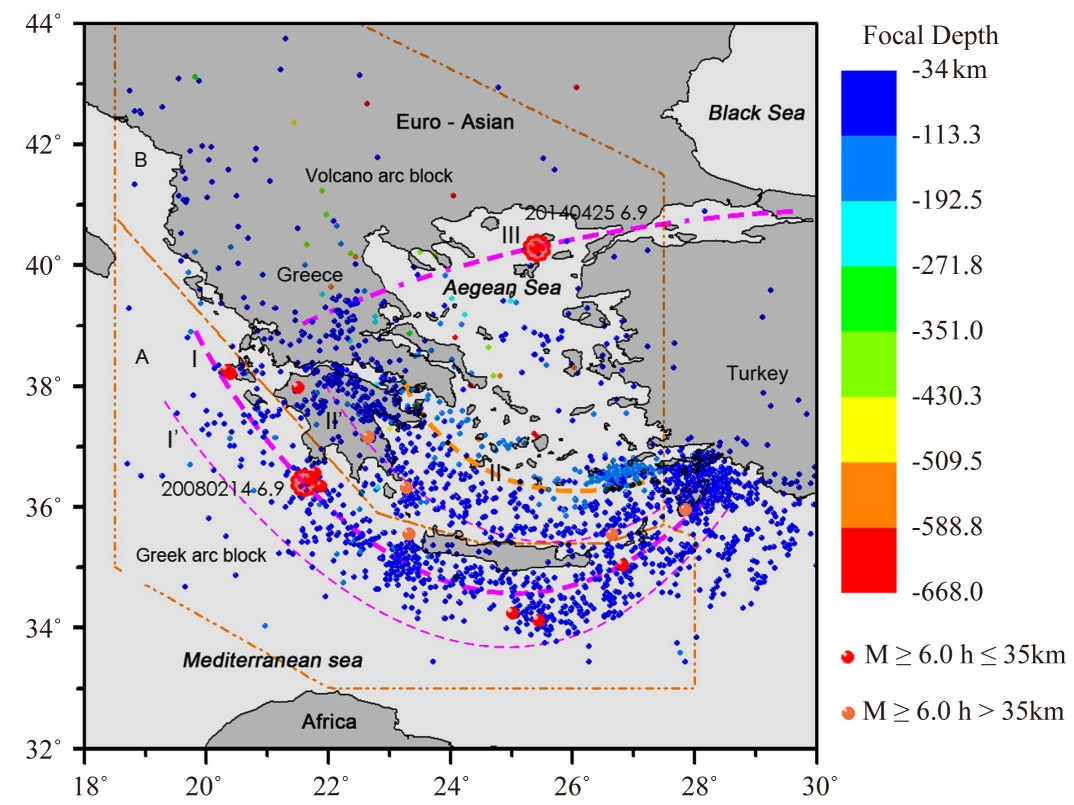

Figure 8. The geographical distribution of subcrustal earthquakes and intracrustal strong earthquakes in the Aegean Sea (Oct.1, 2004 - Oct.1, 2015, M $\geq 1.0$ ).

fine dashed line I' is the Greece front arc, and the yellow fine dashed line II', is the Volcano front arc. The rose thick dashed line III is the western section of the North Anatolian Fault in the graph performance for Volcano back arc, because the volcanic activities in the period of Neoid System in Aegean Sea are limited in the area between the volcanic arc and the North Anatolian Fault, and the volcano eruption times are late and late southward [12]-[45] (Figure 9). Volcanic activity is one of the basic characteristics of seismic cone structure [46] [47]. 


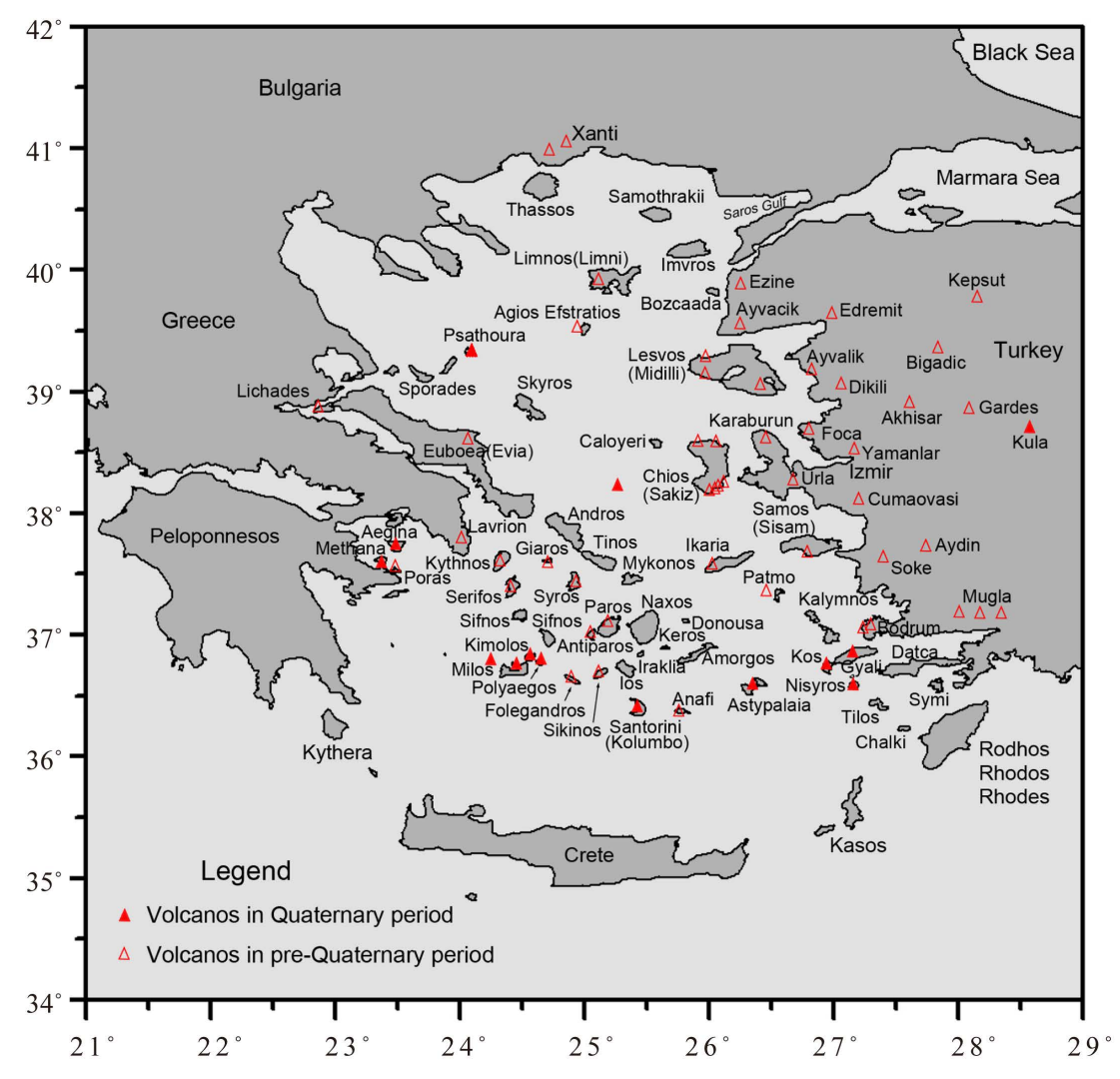

Figure 9. Volcanic activities in the Aegean Sea region.

Worth noting is that four dotted line I, I', II and II', consistently converge in Rhodes island area, Turkey, and scatter to the north-west direction uniform. It indicates that, there seems to be a trend of counter clockwise rotation in this volcanic area which is accurately the center of the Aegean Sea. Because of this case, the author will discuss it in another article.

In order to distinguish the difference between the seismic activity of the Greek arc and the Volcano arc, this paper divides the seismic activity into two blocks: the Greek arc block and the Volcano arc block, and count their monthly frequency (/0.1a) of the seismic activity under the crust, and was shown in Figure 10. From Figure 10, the case can be divided into two sections taking 2009 as node. In the early stage, the monthly frequency of the Greek arc block was significantly higher than that of the Volcano arc block, and the latter was the opposite. The ratio of the monthly frequency of the Greek arc block to the Volcano arc block is significantly greater than 1 in the early stage, and the latter is less than 1. Therefore, there is an earthquake Mw6.9 in February 14, 2008 in southern Greece early, but the later earthquake Mw6.9 in May 24, 2014 was in northern waters of the Aegean Sea. It seems that this figure is a basis for discrimination. We can also found in the figure that 2008 earthquake occurred after the high value of the frequency ratio, and the 2014 earthquake occurred after the high value end of the monthly frequency of the Volcano arc block, i.e. after the lowest level end of the monthly frequency ratio.

The time sequence diagram of the epicenter depth of 2005-2015 in the Turkish Branch Seismic Cone is shown in Figure 11, which shows that before the earthquake Mw6.9 on May 24, 2014 in Aegean Sea, obvious subcrustal seismic activities sign appeared, there was a set of deep seismic activity in 2009-2010 from underground $656 \mathrm{~km}$ straight crust, then it beats in less than $220 \mathrm{~km}$ depth, until an earthquake Mw6.9 occurred. Prior to the earthquake Mw6.9 on February 14, 2008, there was no such activity, possibly due to the lack of seismic data before 2005 year.

The deep seismic activity of 2009-2010 years occurred in one year later after the earthquake Mw6.9 in 2008. It is impossible to be caused by the earthquake in 2008. Moreover, there was no similar deep earthquake activity after the earthquake Mw6.9 in 2014 more than one year. So it is certain that the deep seismic activity of this 


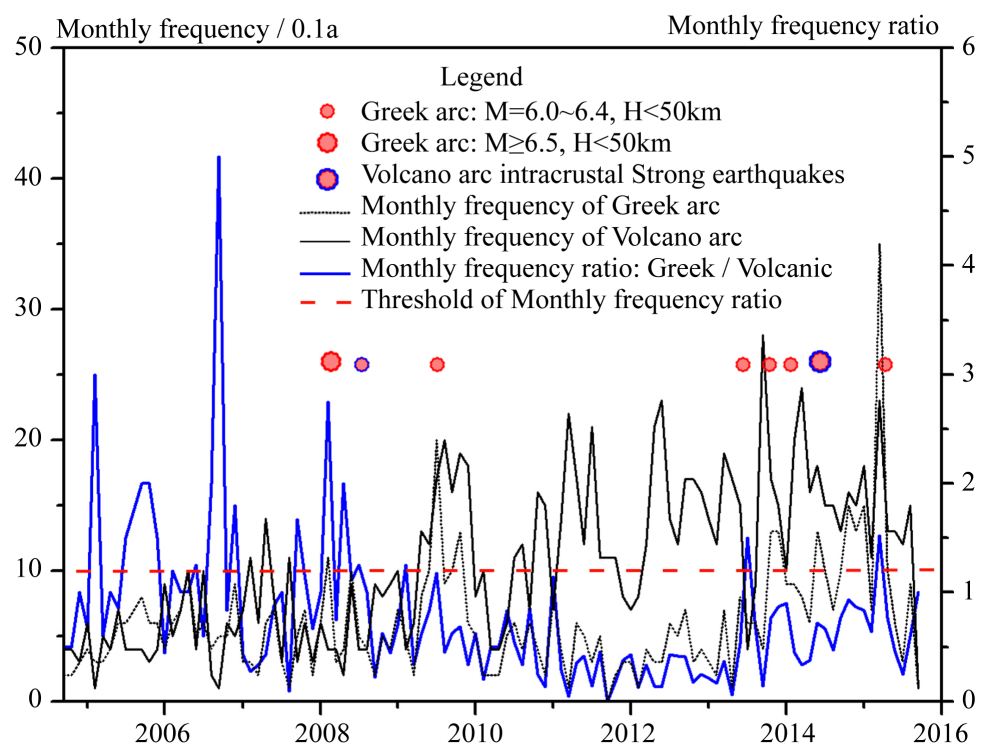

Figure 10. Monthly frequency and its ratio of the subcrustal earthquakes of the Greek arc block and the Volcano arc block in the Aegean Sea Seismic Cone.

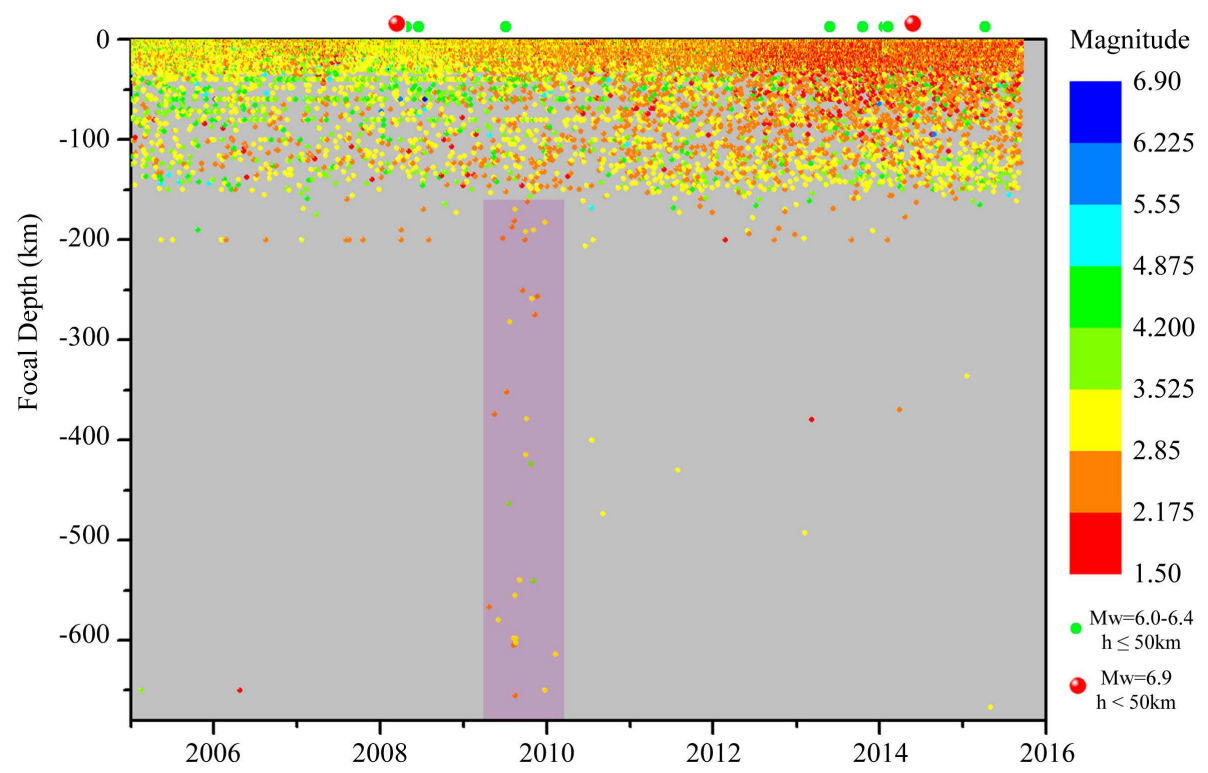

Figure 11. Seismic focal depth sequence diagram of the Turkish Branch Seismic Cone (Jan.1, 2005 - Oct.1, 2015, $\mathrm{M} \geq 1.5$ ).

group is the precursor of the earthquake Mw6.9 in 2014. This phenomenon deserves further study.

\subsection{Seismogenic Process before the Earthquake Mw6.9 on May 24, 2014 in the Aegean Sea}

The subcrustal earthquake activity in the Aegean Sea area from January 1, 2009 to October 1, 2015 is shown in Figure 12. The figure indicates that seismic activity of the Volcano arc block, which was dense seismic at both ends of the Volcano arc, and the red earthquakes under $500 \mathrm{~km}$ depth below constituting a super active layer [5] opening to the northwest, was significantly higher than that of the Greek arc block.

The earthquake focal depth sequence of the Aegean Sea from January 1, 2008 to October 1, 2015 is shown in Figure 13. The diagram shows that after deep source earthquake activities of Aegean Sea Seismic Cone since 


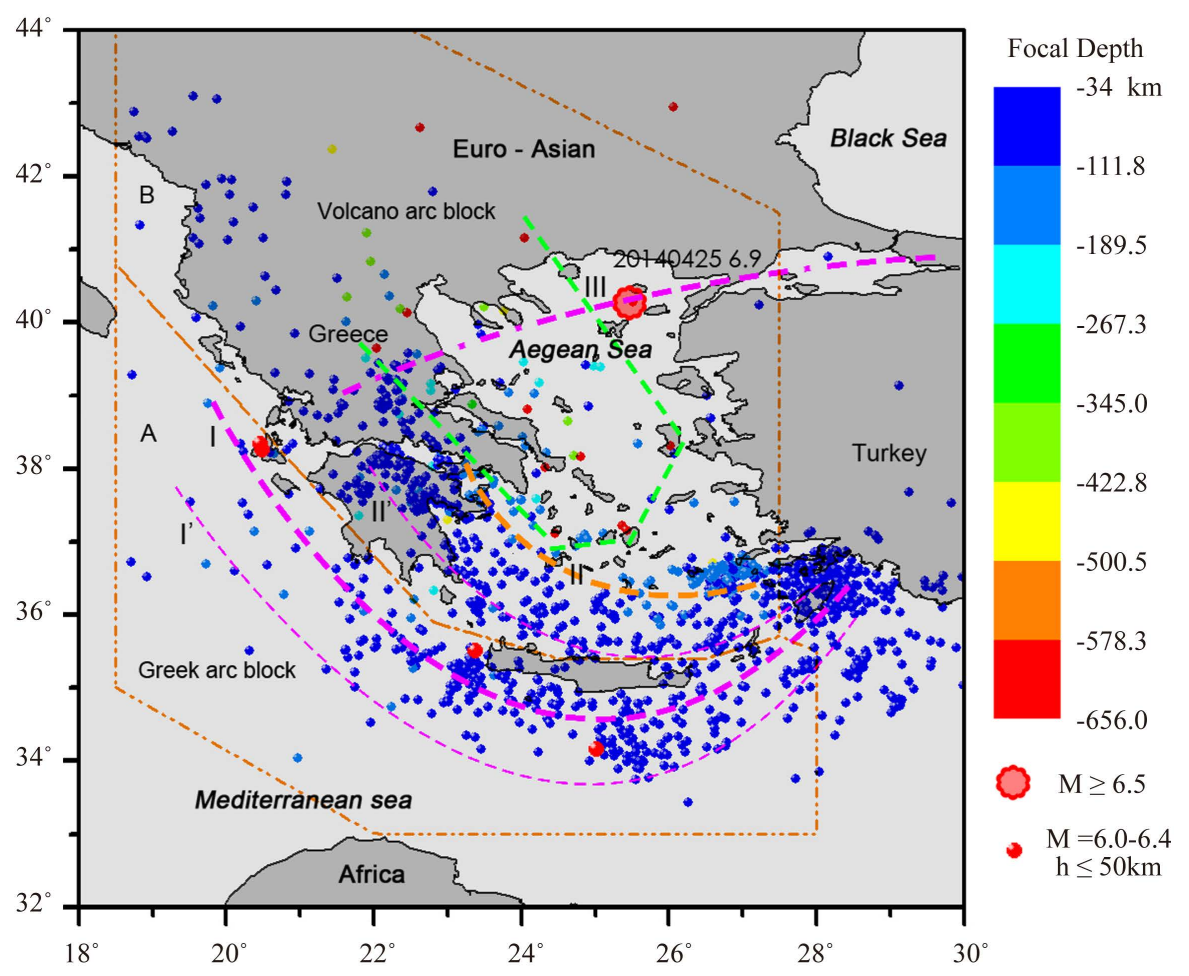

Figure 12. Premonition earthquake distribution of the earthquake Mw6.9 on May 24, 2014 in the northern Aegean Sea (Jan.1, 2009 - Oct. 1, 2015, M $\geq 1.5$ ).

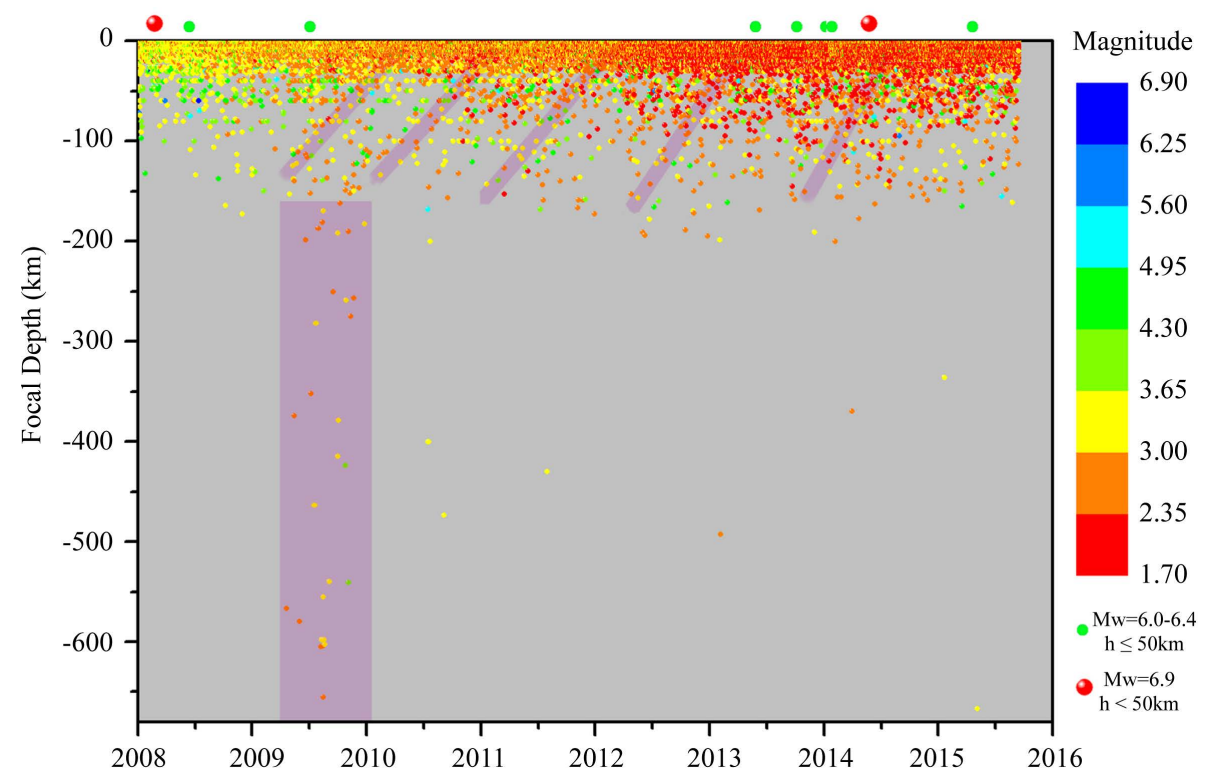

Figure 13. The seismogenic process of the earthquake Mw6.9 on May 24, 2014 in the northern Aegean Sea (Jan.1, 2008 - Oct. 1, 2015, M $\geq 1.7$ ).

2009 there appeared several times of disturbance from bottom to top, fluctuating in the lithosphere within 220 km depth, before and after 2010, 2011, 2013 and before 2014. This was like a stir in the cone body of depth more than 600 kilometers and then caused a series of ripples in the layer close to the ground (lithosphere, within $220 \mathrm{~km}$ depth), to accumulate energy and find a breakthrough release place finally, which was the weak part of the North Anatolian Fault. During the period there was also 4 earthquakes 6+ in the Greek arc block but failed to 
release the energy of the Volcano arc block (Figure 12 and Figure 13). In the image, the process is like a tornado, a storm from the deep mantle to the surface of the Earth.

Figure 14 shows all the seismic sets before the earthquake Mw6.9 from January 1, 2009 to May 24, 2014. Will this picture is decomposed into $0.1 \mathrm{a}$ as a frame of the animation to concentrate the earthquake preparation process of more than 5 years upon ten seconds, the situation is more exciting: after the formation of the earthquake pillar of depth more than $600 \mathrm{~km}$ in 2009-2010, there appeared a number of jumps in the layer of $220 \mathrm{~km}$ depth, until the earthquake occurred (Blog figure 4, gif). Will for Figure 11, taking seismic activity in 2008 as background, and then it is made an animation since 2009 and shown a same effect because of no strong earthquakes around 7 in this period in the Aegean sea outside (Blog figure 6, gif).

However, because this animation cannot be accepted in publishing, we ordered the animation in the web of Seisman's Blog in the Sciencenet web as the indispensable.

Link: http://blog.sciencenet.cn/blog-552558-969802.html

A more than $600 \mathrm{~km}$ deep seismic activity pillar, stirring within $220 \mathrm{~km}$ thick stratum, cause the burst of the weak parts of the crust structure and a strong earthquake. The seismogenic process and seismogenic mechanism of the earthquake Mw6.9 on May 24, 2014 in northern Aegean Sea show that the energy accumulation of a strong earthquake is from deep mantle and it looked for a weak part of the surface structure to break through before the earthquake happened.

\section{Discussion and Conclusion}

\subsection{Discussion and Explanation of Some Problems}

In order to improve the conclusion of this paper, we make a discussion and explanation on the following questions.

1) On the repartition of seismic cones of the Turkish Branch Seismic Cone

Figure 7 shows the results of the repartition of the seismic cones of the Turkish Branch Seismic Cone. It is easy to confuse people if we rely on the future data of the Mediterranean seismic network to be verified. At present, at least the Aegean Sea Seismic Cone is determined. The Aegean Sea Seismic Cone is similar to an onion, and the situation is more complex. Preliminary viewed, the Volcano arc block is like an onion heart and the Greek arc block is like an onion skin. In other words, it looks like that the former is wrapped in the latter by Figure 6 and Figure 14. The data processing is difficult to peel. The results in Figure 10 show two independent activities and their mutual influence and interference. Before the earthquake Mw6.9 in 2014 in the Volcano arc block, monthly frequency ratio is very low. If the monthly frequency ratio is greater than 1 , there will be me-

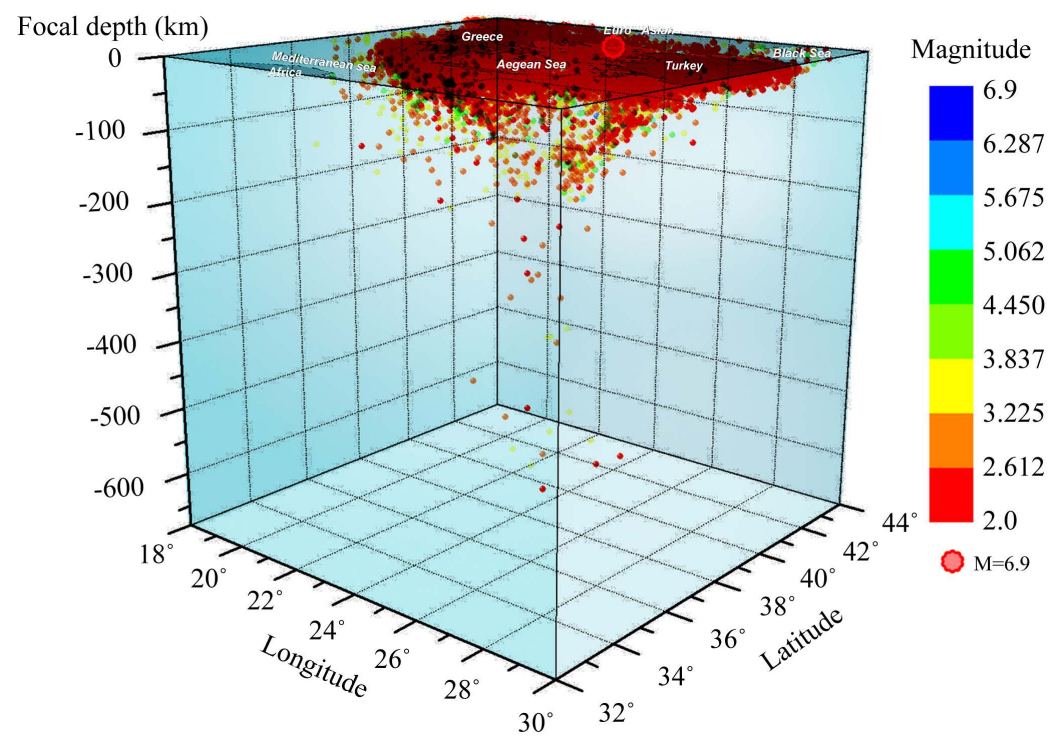

Figure 14. A set of earthquake precursors of the earthquake Mw6.9 on May 24, 2014 in the northern Aegean Sea (Jan.1, 2009 - May 24, 2014, M $\geq 2$ ). 
dium strong earthquake activity in the subcrustal seismic dense zone of the Greek arc block. This suggests the complexity of the problem.

Deep seismic data of the Turkish Seismic Cone is not enough. If another earthquake, such as one in 1999, may be changed it. The intracrustal microseismic activity of the Romanian Seismic Cone is few and deep earthquake activity is a lot more, but there were some strong earthquakes in crust that happened suddenly. It is because that the seismic activity mainly in the lithosphere. The earthquake activity in the Polish Seismic Cone has small strength, but it affects the safety of the local mine, which is worth attention.

It is certain that the depth of the 4 three-level seismic cones is more than $600 \mathrm{~km}$, but it is difficult to discuss because of the lack of seismic data.

2) About the energy of seismic cone pillar

Is the total energy of the seismic cone pillar, as show in Figure 11, sufficient to drive an earthquake Mw6.9? It is unable to make this estimation now. But one thing is clear: deep seismic activity is a characterization of accumulation and transfer of energy. Just like the boiling water, people can see bubble rise and rupture but not heat convection, conduction, and radiation, which is the most part of the energy. Deep seismic cone pillar is more complicated compared with the boiling water.

3) On seismic tectonic model of the Aegean Sea area

This paper studies 4 three-level seismic cones around the Aegean Sea. It is a simple structural model. But there is a deeper problem, that is, the collected evidence is not enough to determine whether the center of Aegean Sea is counterclockwise rotation of the surface structure or not. The popular tectonics mode in the field of geoscience is splice and collision of several "plates" in the Aegean Sea region. One can make some explanation after an earthquake happened, but it seems very difficult to solve problems of earthquake prediction.

\subsection{Conclusion}

In accordance with the Seismo-Geothermics theory about methods of intracrustal strong earthquake and volcano prediction, we use the ANSS earthquake catalogue from the Northern California earthquake data center and the EMSC earthquake catalogue from the European-Mediterranean Seismological Centre to study the seismic activities of the Turkish Branch Cone in the Mediterranean Seismic Cone and the following Aegean Sea Seismic Cone, and show reproduction through graphics and animation, the seismogenic process and seismogenic mechanism of the earthquake Mw6.9 on May 24, 2014 in northern Aegean Sea. It was concluded that the energy of strong earthquake of magnitude around 7 in Aegean Sea was probably from energy transfer and accumulation in deep mantle and incentive lithosphere in the way of wave pattern. Then the strong earthquake occurred suddenly in search of the weak parts of the surface structure. This is a perfect example of that intracrustal strong earthquake is being predicted.

The purpose of this paper is to open a hole in the traditional seismic genesis, and it is beneficial to the further research on the theory and method of earthquake prediction. It is our first attempt to study this case and it needs further examination. In this paper, we divide the Turkish Branch Seismic Cone of the Mediterranean Seismic Cone into 4 tertiary seismic cones, and we show a preliminary seismo-tectonic model of Aegean region. It will be conducive to seismic monitoring and earthquake prediction research in Greece, Turkey, Romania and Poland regions. Due to the high quality earthquake catalogue in these areas, as long as according to the pattern structure of the Figure 7 to change the thinking of the earthquake prediction, outlook is optimistic.

The result of this paper is very difficult to achieve in other areas, because there are only ideal microseismicity data of the Mediterranean Sea and the North America data in author's hand. By contrast, seismic data in China are rich but have poor precision of the focal depth in some regions, which calls for constant improvement. However, the author believes that this strong seismogenic model found in Aegean Sea region could proceed from one point to another. In some other areas of high seismic activity, such as Chile, Philippines, Tonga, Indonesia, Japan, and America, it may provide more examples by using the ANSS earthquake catalog or local high quality earthquake catalogues [48] [49]. At present, the world's earthquake prediction has little effect, and it even tends to be not cognitive. Innovative thinking is the only way out.

\section{Acknowledgements}

For this study, the ANSS catalog was accessed through the Northern California Earthquake Data Center (NCEDC), doi: 10.7932/NCEDC, and the EMSC catalog was accessed through the European-Mediterranean 
Seismological Centre. The author thanks else the China Earthquake Administration for Old expert research Fund Project No. 201601.

\section{References}

[1] Chen, L.J. (2000) Research of Focal Depth and Active State of the Strong Earthquakes in China. Seismology and Geology, 22, 360-370.

[2] Chen, L.J. (2012) Theory and Application of Seismo-Geothermics. Inland Earthquake, 26, 108-122.

[3] Chen, L.J. (2013) Concept and Basic Characteristics of Seismic Cylinder. South China Journal of Seismology, 33, 114.

[4] Chen, L.J. (2015) Summary of the Test of 0419 Forecast Card (3 Years) in 2012-Recommend on the Methods of Intracrustal Strong Earthquake Prediction and Volcanic Prediction by the Theory of Seismo-Geothermics. Open Journal of Natural Science, 3, 147-164. http://dx.doi.org/10.12677/OJNS.2015.34019

[5] Chen, L.J., Chen, X.F., Wan, F.F., Li, P.Z. and Shao, L. (2015) Comparative Study of Global Seismicity on the Hot Engine Belt and the Cooling Seismic Belt-Improvement on Research Ideas of Earthquake Prediction. International Journal of Geosciences, 6, 741-749. http://dx.doi.org/10.4236/ijg.2015.67060

[6] Chen, L.J., Chen, X.F. and Shao, L. (2015) Method Research of Earthquake Prediction and Volcano Prediction in Italy. International Journal of Geosciences, 6, 963-971. http://dx.doi.org/10.4236/ijg.2015.69076

[7] Chen, L.J. (2015) Pakistan Earthquake with Ms7.7 in 2013 and Causative Structure of Hindu Kush. Inland Earthquake, 29, 15-27.

[8] Chen, L.J. (2013) Seismo-Tectonics and Seismic Activity of the Qinghai-Tibet Plateau. Journal of Seismological Research, 36, 123-131.

[9] USGS (2015) Earthquakes with 1,000 or More Deaths 1900-2014. http://earthquake.usgs.gov/earthquakes/world/world_deaths.php

[10] Li, S.G. (1972) Astronomy, Geology and Paleontology. Science Press, Beijing, 71-115.

[11] Li, S.G. (1976) Method of Geomechanics. Science Press, Beijing.

[12] Calvo, J.P., Triantaphyllou, M.V., Regueiro, M. and Stamatakis, M. (2012) Alternating Diatomaceous and Volcaniclastic Deposits in Milos Island, Greece. A Contribution to the Upper Pliocene-Lower Pleistocene Stratigraphy of the Aegean Sea. Palaeogeography, Palaeoclimatology, Palaeoecology, 321-322, 24-40. http://dx.doi.org/10.1016/j.palaeo.2012.01.013

[13] Kinvig, H.S., Winson, A. and Gottsmann, J. (2010) Analysis of Volcanic Threat from Nisyros Island, Greece, with Implications for Aviation and Population Exposure. Natural Hazards and Earth System Sciences, 10, 1101-1113. http://dx.doi.org/10.5194/nhess-10-1101-2010

[14] Kougioumoutzis, K., Tiniakou, A., Georgiou, O. and Georgiadis, T. (2012) Contribution to the Flora of the South Aegean Volcanic Arc: Anafi Island (Kiklades, Greece). Willdenowia-Annals of the Botanic Garden and Botanical Museum Berlin-Dahlem, 42, 127-141. http://dx.doi.org/10.3372/wi.42.42115

[15] Kougioumoutzis, K., Tiniakou A., Georgiou, O. and Georgiadis, T. (2014) Contribution to the Flora of the South Aegean Volcanic Arc: Kimolos Island (Kiklades, Greece). Edinburgh Journal of Botany, 71, 135-160. http://dx.doi.org/10.1017/S0960428614000055

[16] Kougioumoutzis, K. and Tiniakou, A. (2015) Ecological Factors Driving Plant Species Diversity in the South Aegean Volcanic Arc and Other Central Aegean Islands. Plant Ecology \& Diversity, 8, 173-186. http://dx.doi.org/10.1080/17550874.2013.866989

[17] Nomikou, P. and Papanikolaou, D. (2011) Extension of Active Fault Zones on Nisyros Volcano across the Yali-Nisyros Channel Based on Onshore and Offshore Data. Marine Geophysical Researches, 32, 181-192. http://dx.doi.org/10.1007/s11001-011-9119-z

[18] Megalovasilis, P. and Godelitsas, A. (2015) Hydrothermal Influence on Nearshore Sediments of Kos Island, Aegean Sea. Geo-Marine Letters, 35, 77-89. http://dx.doi.org/10.1007/s00367-014-0393-z

[19] Megalovasilis, P. (2014) Partition Geochemistry of Hydrothermal Precipitates from Submarine Hydrothermal Fields in the Hellenic Volcanic Island Arc. Geochemistry International, 52, 992-1010. http://dx.doi.org/10.1134/S0016702914110044

[20] Kondopoulou, D., Senb, S., Aidonaa, E., van Hinsbergenc, D.J.J. and Koufos, G. (2011) Rotation History of Chios Island, Greece since the Middle Miocene. Journal of Geodynamics, 51, 327-338. http://dx.doi.org/10.1016/j.jog.2010.07.001

[21] Bradley, K.E., Vassilakis, E., Hosa, A. and Weiss, B.P. (2013) Segmentation of the Hellenides Recorded by Pliocene 
Initiation of Clockwise Block Rotation in Central Greece. Earth and Planetary Science Letters, 362, 6-19. http://dx.doi.org/10.1016/j.epsl.2012.11.043

[22] Nomikou, P., Carey, S., Papanikolaou, D., Croff Bell, K., Sakellariou, D., Alexandri, M. and Bejelou, K. (2012) Submarine Volcanoes of the Kolumbo Volcanic Zone NE of Santorini Caldera, Greece. Global and Planetary Change, 90-91, 135-151. http://dx.doi.org/10.1016/j.gloplacha.2012.01.001

[23] Pe-Piper, G. and Piper, D.J.W. (2013) The Effect of Changing Regional Tectonics on an Arc Volcano: Methana, Greece. Journal of Volcanology and Geothermal Research, 260, 146-163. http://dx.doi.org/10.1016/j.jvolgeores.2013.05.011

[24] Bachmann, O. (2010) The Petrologic Evolution and Pre-Eruptive Conditions of the Rhyolitic Kos Plateau Tuff (Aegean Arc). Central European Journal of Geosciences, 2, 270-305. http://dx.doi.org/10.2478/v10085-010-0009-4

[25] Livanos, I., Nomikou, P., Papanikolaou, D. and Rousakis, G. (2013) The Volcanic Debris Avalanche on the SE Submarine Slope of Nisyros Volcano, Greece: Geophysical Exploration and Implications for Subaerial Eruption History. Geo-Marine Letters, 33, 419-431. http://dx.doi.org/10.1007/s00367-013-0338-y

[26] Dimopoulos, P., Raus, T., Mucina, L. and Tsiripidis, I. (2010) Vegetation Patterns and Primary Succession on SeaBorn Volcanic Islands (Santorini Archipelago, Aegean Sea, Greece). Phytocoenologia, 40, 1-14. http://dx.doi.org/10.1127/0340-269X/2010/0040-0426

[27] Andújar, J., Scaillet, B., Pichavant, M. and Druitt, T.H. (2015) Differentiation Conditions of a Basaltic Magma from Santorini, and Its Bearing on the Production of Andesite in Arc Settings. Journal of Petrology, 56, 765-794. http://dx.doi.org/10.1093/petrology/egv016

[28] Innocenti, F., Kolios, N., Manetti, P., Rita, F., Villari, L. and Villari, L. (1982) Acid and Basic Late Neogene Volcanism in Central Aegean Sea: Its Nature and Geotectonic Significance. Bulletin of Volcanology, 45, 87-97. http://dx.doi.org/10.1007/BF02600426

[29] Altunkaynak, S., Rogers, N.W. and Kelley, S.P. (2010) Causes and Effects of Geochemical Variations in Late Cenozoic Volcanism of the Foça Volcanic Centre, NW Anatolia, Turkey. International Geology Review, 52, 579-607. http://dx.doi.org/10.1080/00206810903360455

[30] Kougioumoutzis, K., Tiniakou, A., Georgiou, O. and Georgiadis, T. (2015) Contribution to the Flora and Biogeography of the Kiklades: Folegandros Island (Kiklades, Greece). Edinburgh Journal of Botany, 72, 391-412. http://dx.doi.org/10.1017/s0960428615000128

[31] Huber, H. and Bichler, M. (2003) Geochemical Correlation of Archaeological Sites Using Tephra from the Minoan Eruption. Czechoslovak Journal of Physics, 53, A439-A453. http://dx.doi.org/10.1007/s10582-003-0057-0

[32] Bröcker, M. and Keasling, A. (2006) Ionprobe U-Pb Zircon Ages from the High-Pressure/Low-Temperature Mélange of Syros, Greece: Age Diversity and the Importance of Pre-Eocene Subduction. Journal of Metamorphic Geology, 24, 615-631. http://dx.doi.org/10.1111/j.1525-1314.2006.00658.x

[33] Roussakis, G., Karageorgis, A.P., Conispoliatis, N. and Lykousis, V. (2004) Last Glacial-Holocene Sediment Sequences in N. Aegean Basins: Structure, Accumulation Rates and Clay Mineral Distribution. Geo-Marine Letters, 24, 97-111. http://dx.doi.org/10.1007/s00367-004-0167-0

[34] Liati, A., Skarpelis, N. and Pe-Piper, G. (2009) Late Miocene Magmatic Activity in the Attic-Cycladic Belt of the Aegean (Lavrion, SE Attica, Greece): Implications for the Geodynamic Evolution and Timing of Ore Deposition. Geological Magazine, 146, 732-742. http://dx.doi.org/10.1017/S0016756809006438

[35] Baltatzis, E., Kostopoulos, D., Godelitsas, A., Zachariadis, P. and Papanikolaou, D. (2009) Pliocene Tourmaline Rhyolite Dykes from Ikaria Island in the Aegean Back-Arc Region: Geodynamic Implications. Geodinamica Acta, 22, 189199. http://dx.doi.org/10.3166/ga.22.189-199

[36] Augier, R., Jolivet, L., Gadenne, L., Lahfid, A. and Driussi, O. (2015) Exhumation Kinematics of the Cycladic Blueschists Unit and Back-Arc Extension, Insight from the Southern Cyclades (Sikinos and Folegandros Islands, Greece). Tectonics, 34, 152-185. http://dx.doi.org/10.1002/2014tc003664

[37] Mitropolous, P., Tarney, J., Saunders, A.D. and Marsh, N.G. (1987) Petrogenesis of Cenezoic Volcanic Rocks from the Aegean Island Arc. Journal of Volcanology and Geothermal Research, 32, 177-193. http://dx.doi.org/10.1016/0377-0273(87)90043-6

[38] Sterba, J.H., Steinhauser, G. and Bichler, M. (2011) On the Geochemistry of the Kyra Eruption Sequence of Nisyros Volcano on Nisyros and Tilos, Greece. Applied Radiation and Isotopes, 69, 1605-1612. http://dx.doi.org/10.1016/j.apradiso.2011.04.013

[39] Steinhauser, G., Hujer, W., Sterba, J.H., Seemann, R., Bichler, M. and Symeonidis, N. (2008) On Strontium and Barium Anomalies in the Sediments of Charkadio Cave (Tilos Island, Dodekanese, Greece). Journal of Radioanalytical and Nuclear Chemistry, 276, 167-173. http://dx.doi.org/10.1007/s10967-007-0427-3

[40] Maravelis, A.G., Pantopoulos, G., Tserolas, P. and Zelilidis, A. (2015) Accretionary Prism-Forearc Interactions as Re- 
flected in the Sedimentary Fill of Southern Thrace Basin (Lemnos Island, NE Greece). International Journal of Earth Sciences, 104, 1039-1060. http://dx.doi.org/10.1007/s00531-014-1130-6

[41] Borsi, S., Ferrara, G., Innocenti, F. and Mazzuoli, R. (1972) Geochronology and Petrology of Recent Volcanics in the Eastern Aegean Sea (West Anatolia and Lesvos Island). Bulletin of Volcanology, 36, 473-496. http://dx.doi.org/10.1007/BF02597122

[42] Aksu, A.E., Jenner, G., Hiscott, R.N. and İşler, E.B. (2008) Occurrence, Stratigraphy and Geochemistry of Late Quaternary Tephra Layers in the Aegean Sea and the Marmara Sea. Marine Geology, 252, 174-192. http://dx.doi.org/10.1016/j.margeo.2008.04.004

[43] Seyitoglu, G. and Scott, B.C. (1992) Late Cenozoic Volcanic Evolution of the Northeastern Aegean Region. Journal of Volcanology and Geothermal Research, 54, 157-176. http://dx.doi.org/10.1016/0377-0273(92)90121-S

[44] Yanev, Y., Boev, B., Doglioni, C., Innocenti, F., Manetti, P., Pecskay, Z., Tonarini, S. and D’Orazio, M. (2008) Late Miocene to Pleistocene Potassic Volcanism in the Republic of Macedonia. Mineralogy and Petrology, 94, 45-60. http://dx.doi.org/10.1007/s00710-008-0009-2

[45] Nomikou, P., Katherine, L., Bell, C., Papanikolaou, D., Livanos, I. and Martin, J.F. (2013) Exploring the Avyssos-Yali-Strogyli Submarine Volcanic Complex at the Avyssos-Yali-Strogyli Submarine Volcanic Complex at the Eastern Edge of the Aegean Volcanic Arc. Zeitschrift für Geomorphologie, Supplementary Issues, 57, 125-137. http://dx.doi.org/10.1127/0372-8854/2013/S-00147

[46] Chen, L.J., Hu, F.X. and Chen, X.F. (2013) Imaging Proof of Seismic Tomography in Seismic Cones on the Earth. South China Journal of Seismology, 33, 1-10.

[47] Chen, L.J. (2015) Comparative Study of Global Volcano Activities on the Hot Engine Belt and the Cooling Seismic Belt-Improvement on Research Ideas of Volcano Prediction on the Hot Engine Belt. Advances in Geosciences, 5, 334-357. http://dx.doi.org/10.12677/AG.2015.55034

[48] Chen, L.J. (2014) Discussion on Earthquake Causes in Middle Tianshan Region by an Example of the Earthquake Ms6.6 on June 30, 2012 in Xinyuan Region.

[49] Chen, L.J. (2015) An Earthquake Precursory Phenomenon of the Earthquake Ms5.8 in Alashan Zuoqi Region, Inner Mongolia. 